\title{
DIVERSITY OF BENTHIC MACROINVERTEBRATES IN MARGARAÇA FOREST STREAMS (PORTUGAL).
}

\author{
Manuela Abelho \\ Departamento de Zoologia, Universidade de Coimbra, 3000 Coimbra, Portugal
}

Palabras Clave: biodiversidad, comunidades de macroinvertebrados acuáticos, grupos funcionales

Keywords: biodiversity, stream macroinvertebrate communities, functional feeding groups.

\begin{abstract}
Structure and diversity of the benthic macroinvertcbrate fauna were studied in two deciduous forest streams in Central Portugal. In the three sampling occasions. 120 taxa were collected from the two streams. Number of taxa per sampling occasion ranged from 53 to 60. Macroinvertebrate densities ranged from 1465 to 2365 . Insects were the most abundant taxonomic group ( $\geq 80 \%$ ) in all samples. Detritivorous invertebrates were numerically dominant in both streams, representing 62 to $85 \%$ of the total macroinvertebratc community.
\end{abstract}

\section{INTRODUCTION}

Margaraqa Forest is a Natural Reserve (Protected Area of Serra do Açor, D.L. 67/82. $3^{\text {rd }}$ March). It is a very old forest dominated by chestnuts (Castanea sativa Miller) and oaks (Quercus robur L.). Less abundant elements are Portuguese laurel cherries (Prunus lusitanica L. ssp lusitanica), laurels (Laurus nobilis L.). hollies (Hex aquifolium L.). arbutus (Arbutus unedo L.), hazels (Corylus avellana L.), cherries (Prunus avium L.) and morellos (Prunus cerasus L.). The understorey is predominantly composed of butcher's brooms (Ruscus aculeatus L.), blackberry bushes (Rubus coutinhoi Samp.), woodbines (Lonicera periclymenum L. ssp. periclymenum), etc. Several species of ferns can also be observed, as well as other rare plants of the Portuguese flora (PAIVA. 1981).

Biodiversity patterns are directly and indirectly influenced by the gcomorphology of riverine landscapes (WARD, 1998). Margaraça Forest represents one of the last examples of the original vegetation of the schistous slopes in Central Portugal. According to CRISP et al. (1998), areas with a large proportion of native vegetation preserve the maximum number of other natıve species, such as invertebrates. A site containing high plant species diversity is likely to provide a greater range of invertebrate habitats (CRISP et al., 1998). Bccause many terrestrial insects have aquatic larval instars, their development depends on the surrounding vegetation in two ways; while they live underwater and after their emergence as terrestrial adults. Thus. it is possible that the aquatic communities arc also positively influenced by the high plant species diversity of the forest.

Several low order streams abundantly irrigate Margaraça Forest; nevertheless, no effort has been so far done to provide information about the aquatic invertebrates of these streams.

The aim of this work was to generate baseline data on the henthic macroinvertebratc communities of two streams flowing through Margaraça Forest, in order to assess the faunistic importance of these woods and to provide basis for the necessity of conservation of our natural patrimony.

\section{MATERIAL AND METHODS}

Margaraça Forest occupies an area of approximately 50 ha, it is exposed to N-NW and has a slope of $25^{\circ}$, between 600 and $850 \mathrm{~m}$ of altitude. It is located in Scrra do Açor, near Coimbra (Fig.l). The two streams in study are orders 1 (Stream I) and 3 (Stream 2). Basin drainage areas are 29 ha for Stream 1 and 182 ha for Stream 2.

Invertebrate sampling was performed in three times: autumn (December 1991), winter (March 1992) and 


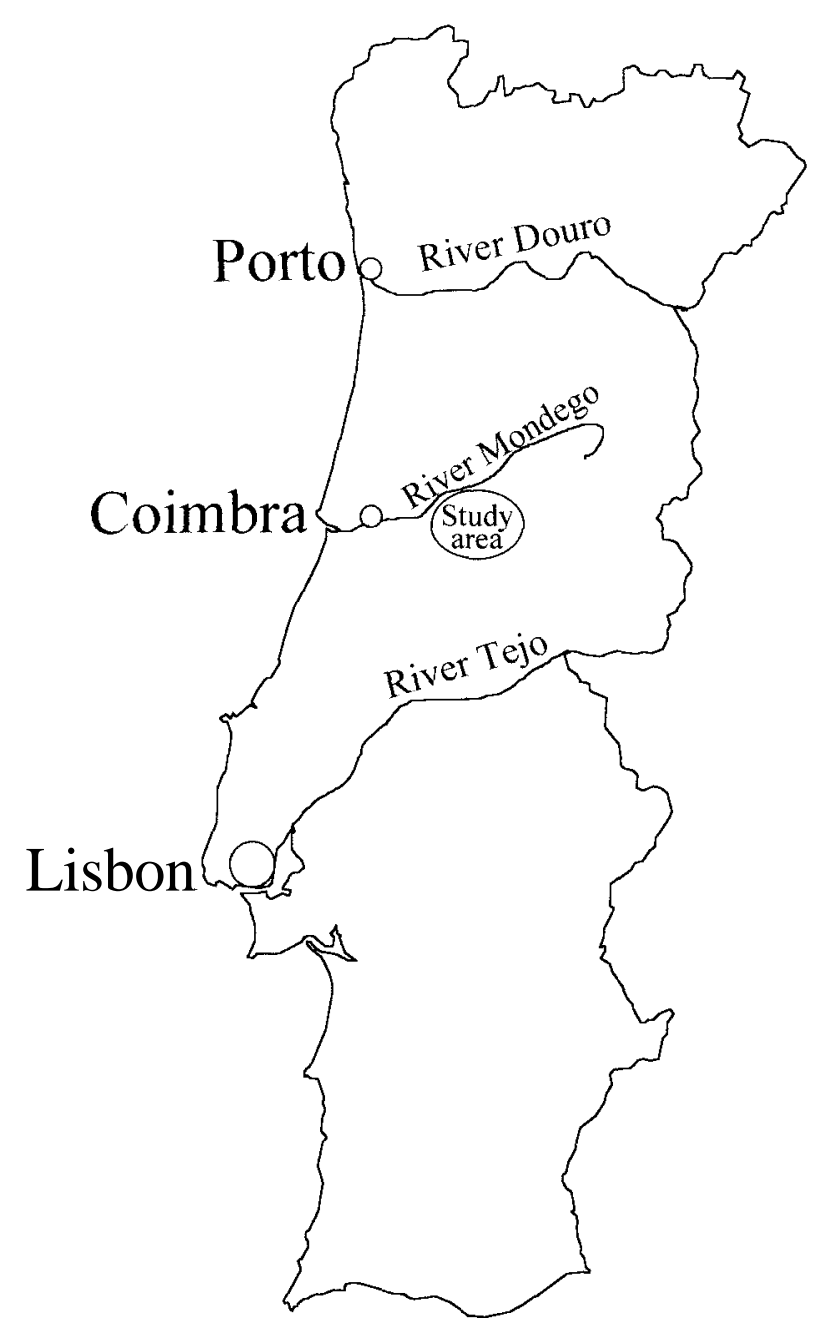

Figure I. Location of the study area in Central Portugal. ,

summer (September 1992). In each stream, 6 samplcs were taken with a surber-net $(0.3 \mathrm{~m} \times 0.3 \mathrm{~m} ; 0.5 \mathrm{~mm}$ mesh). The samples were brought to the laboratory, washed thoroughly and screened with a mesh of $0.5 \mathrm{~mm}$. The 6 samples collected from each stream in each sampling occasion were treated as replicates. The arithmetic means were calculated from these replicates and the results wcre converted to number of individuals per unit area $\left(1 \mathrm{~m}^{2}\right)$. Identification of the animals was carried out to the lowest possible taxonomic level, according to the available taxonomic keys.

Animals were classified into functional feeding groups according to MERRITT \& CUMMINS (1996) and to TACHET et al. (1981). Differences between streams were tested by the Mann-Whitney non-parametric test (U;ZAR. 1996).

\section{RESULTS}

During the study period, 120 taxa of macroinvertebrates were identified in the samples collected from the 2 streams (Appcndix). These included the following taxonomic groups: Tricladida, Nematoda, Gastropoda, Lamellibranchiata, Oligochaeta, Hirudinea, Hydracarina, Isopoda, Collembola and Insecta. Insects werc the most abundant group ( $\geq 80 \%$ of total animals in all samples; Fig. 2), representing 6 orders: Ephemeroptera, Plecoptera, Odonata, Coleoptera, Trichoptera and Diptera (Fig. 3).

Identification of some groups was incomplete; Nematoda, Hydracarina, Isopoda and Collembola were not further identified. In many other cases, identification was carried out only to family level. The incomplete identification of many animals probably resulted in an under-estimation of the total number of taxa..

From the functional point of view, the two streams were dominated by detritivorcs (such as the Leuctridae), which constituted $62-85 \%$ of the total macroinvertebrate community. Scrapers represented $7-22 \%$ of the invertebrates, and predators $3-15 \%$ (Fig. 4).

\section{Seasonal variation}

The mean population density of benthic macroinvertebrates ranged from $1465 \mathrm{~m}^{-2}$ in summer to $2365 \mathrm{~m}^{-2}$ in winter in Stream I and from $1477 \mathrm{~m}^{-2}$ in summer to $1957 \mathrm{~m}^{-2}$ in winter in Stream 2. The nurnber of taxa ranged from 60 in winter to 53 in summer in Stream 1 and from 60 in winter to 37 in summer in Stream 2 (Appendix). Insects (Fig. 2) werc morc abundant in winter (90\% in Stream 1; $88 \%$ in Stream 2) and less abundant in summer (85\% in Stream 1;80\% in Stream 2). The taxonomic composition of the insects (Fig. 3) varied between seasons. In autumn, Diptera was the most abundant order (67\% of total insects in Stream 1; $49 \%$ in Stream 2). followed by Plecoptera (21\% in Stream 1, 37\% in Strearn 2). In winter, Diptera again was the dominant order $(81 \%$ in Stream 1;37\% in Stream 2), followed by Plecoptera (9\%) in Stream I and by Ephemeroptera (32\%) in Stream 2. Finally, in summer, Plecoptera was the dominant order $(64 \%)$ in Stream 1, followed by Diptera (29\%). In Stream 2, Diptera was more abundant (48\%) followed by Plecoptera (38\%).

The taxa found in the streams of Margaraça Forest during the study period can be divided into 3 arbitrary groups: (I) abundant taxa occurring regularly, (2) taxa occurring occasionally and (3) taxa occurring more or less regularly but not in great numbers at any time (Appendix). In group (1) 6 taxa wcrc abundant in both streams (A, Appcndix), 3 taxa were 


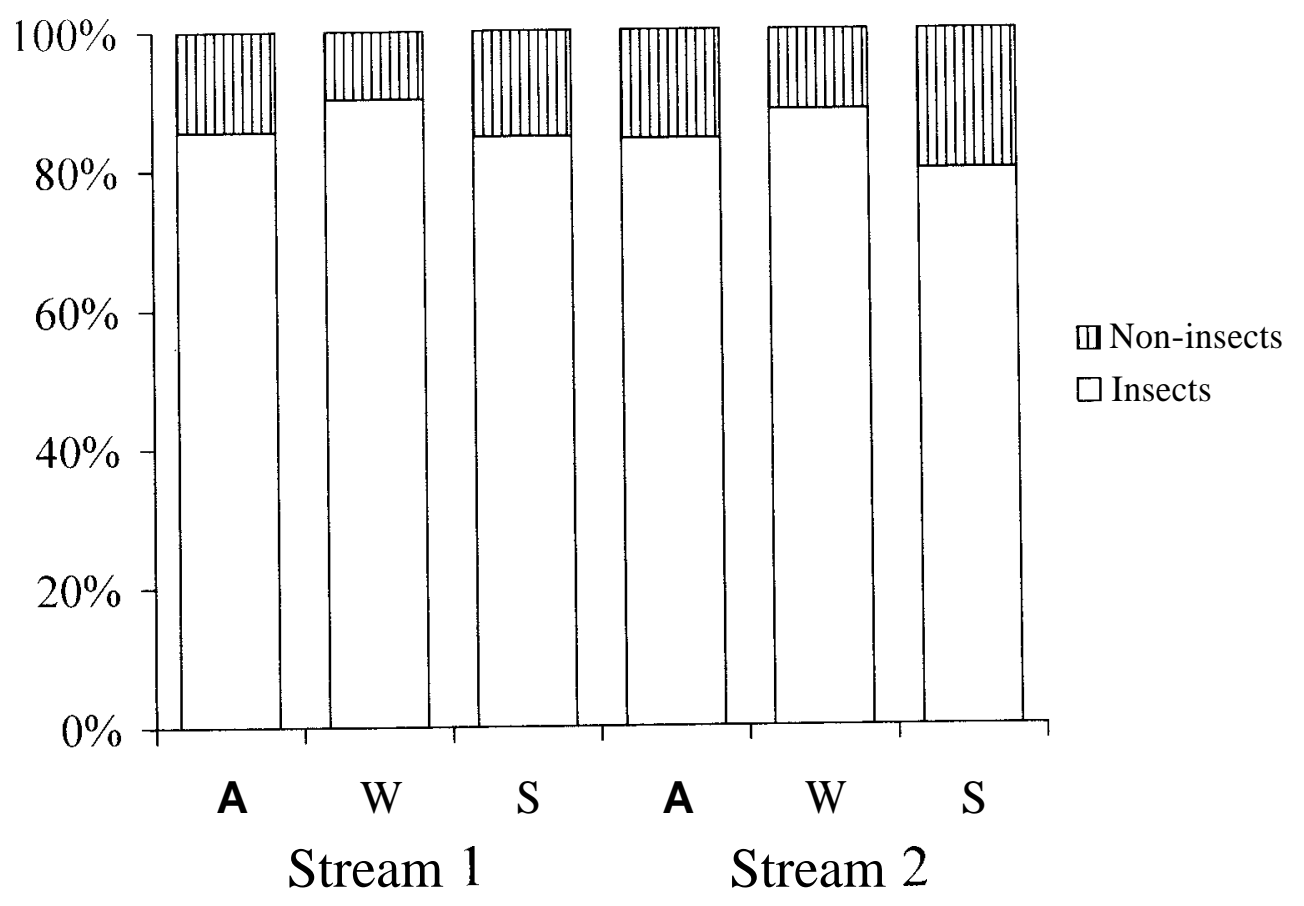

Figure 2. Seasonal variations in the percentage of insects and non-1nsects in the two streams $A=$ autumn. $W=$ winter. $S=s u m m e r$

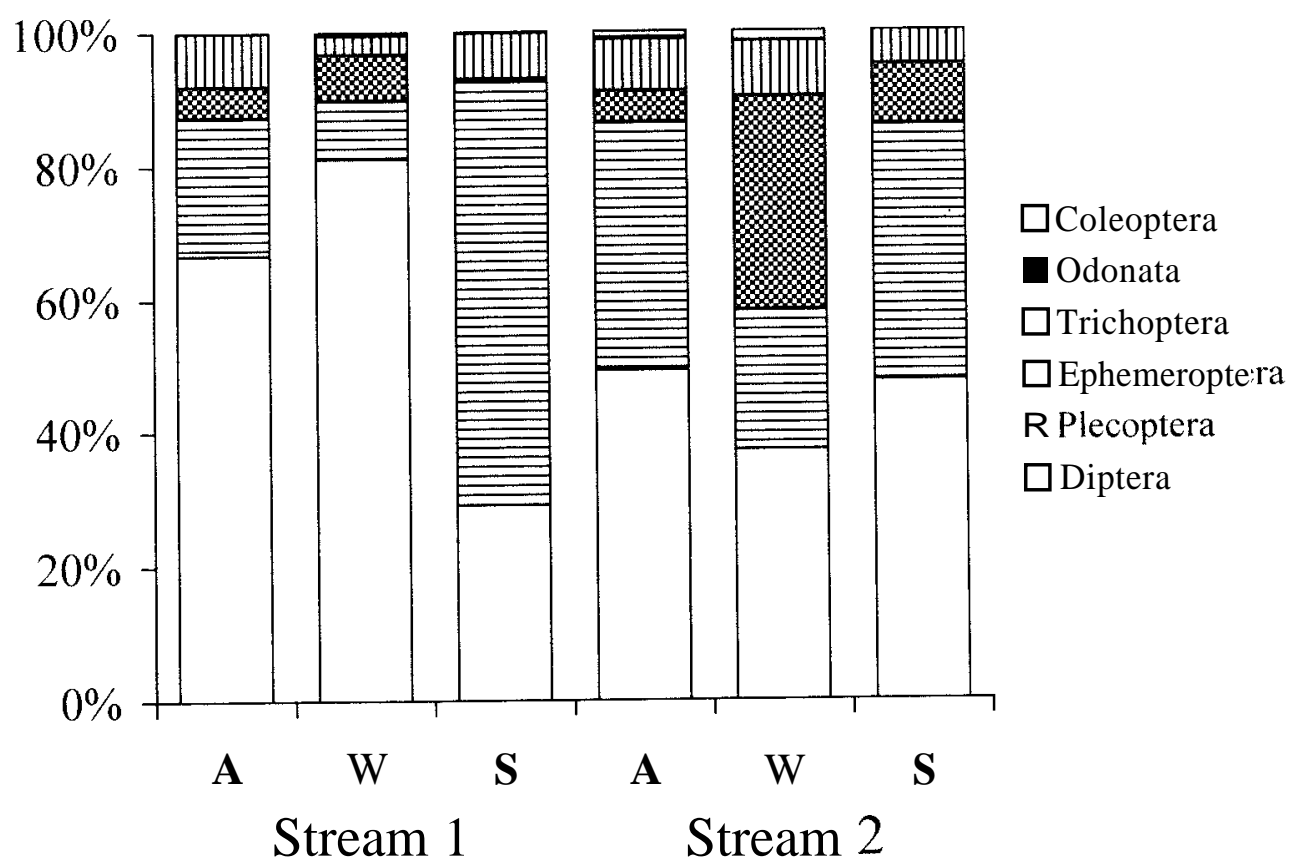

Figure 3. Seasonal vartations in the relative contribution of insect orders in the two streams. $\Lambda=$ autumn, $W=$ winter, $S=$ summer 


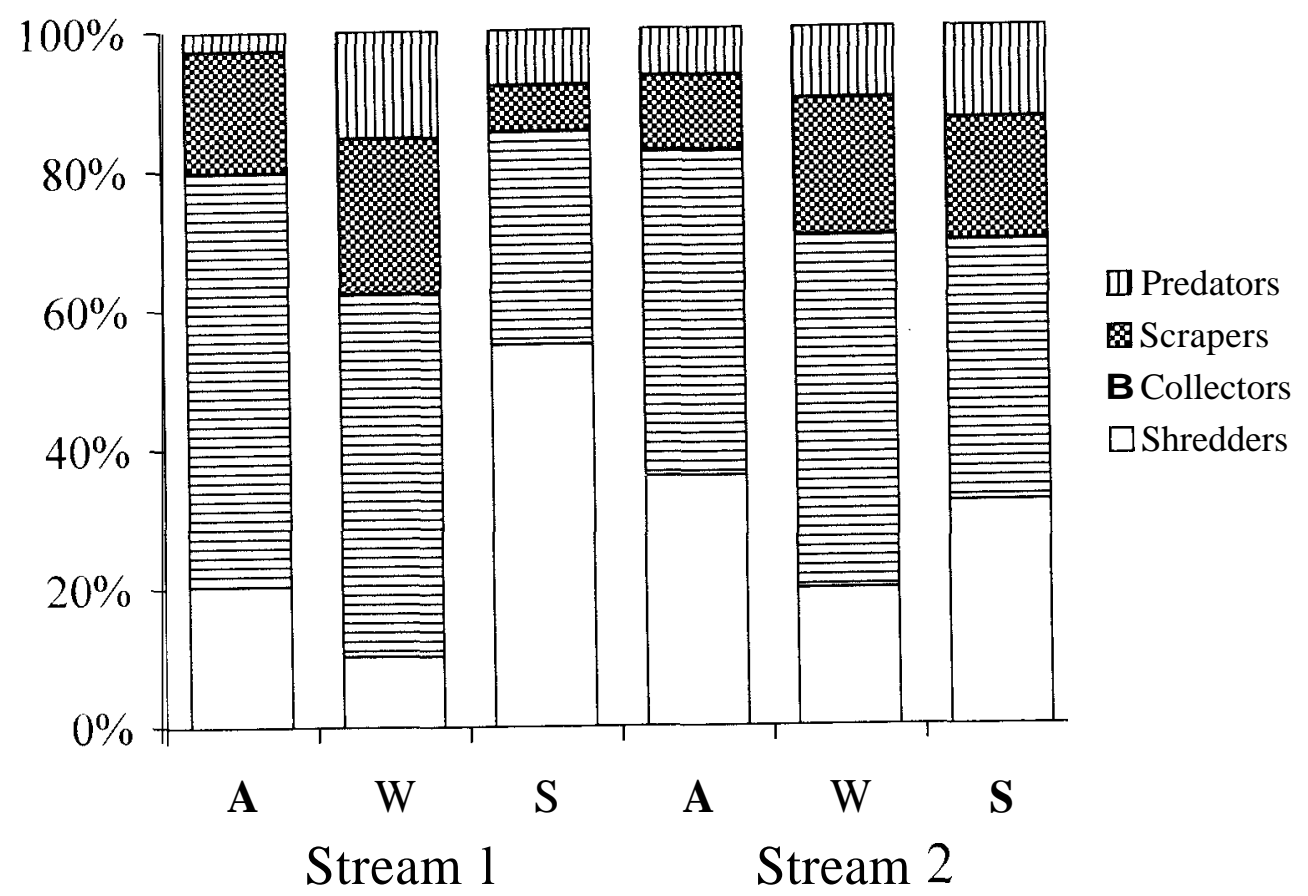

Figure 4. Seasonal variations in the percentage of functional feeding groups in the two streams. $A=$ autumn, $W=$ wtnter. $S=$ summer

abundant in Stream 1 ( $\mathrm{A}_{1}$, Appcndix), and 4 taxa were abundant in Stream 2 ( $\mathrm{A}_{2}$, Appendix). In group (2) 24 taxa were regular in both strcams ( $\mathrm{R}$, Appendix), 18 taxa were regular in Stream $1\left(\mathrm{R}_{1}\right.$, Appcndix), and 13 taxa were abundant in Stream 2 ( $\mathrm{R}_{2}$, Appendix). In group (3) 7 taxa were occasional in both streams (O, Appendix), 32 taxa wcre occasional in Stream $1\left(\mathrm{O}_{1}\right.$, Appendix $)$, and 28 taxa wcre occasional in Stream $2\left(\mathrm{O}_{2}\right.$, Appendix $)$.

\section{Spatial distribution}

The rnean population density and the number of taxa wcre not significantly different between streams $(\mathbf{U}<6, \mathrm{DF}=1$, $\mathrm{P}<0.05$ ). On the basis of spatial distribution, the taxa can be divided into 2 major groups: (I) thosc occurring in both streams and (2) thosc occurring exclusively in one of the streams. Of the 120 taxonomic groups, 37 occurred exclusively in Stream 1 and 30 occurrcd exclusively in Stream 2 (Appendix). However, most of thcsc taxa were occasional; only 9 regular or abundant taxa (Nematoda, Gastropoda unidentificd 1, Rhyacophila adjunctaddenticulata, Plectrocnemia geniculata, Micropterna sp, Crunoecia irrorata, Helius sp, Dicranota sp and Psychodidae unidentified 2) occurred exclusively in Stream 1 and 8 regular or abundant taxa (Ephemera glaucops, Ephemera lineata, Calopteryx virgo, Elmis sp (larvae), Hydropsyche bulbifera, Lithax niger, Lepidostoma hirtum and Dixa maculata) occurrcd exclusively in Stream 2 (Appendix).

\section{DISCUSSION}

Although the two streams arc geographically very close, differences in taxonomic composition as well as in seasonal patterns could be observed. Stream I is much smaller than Stream 2, and completely shaded by the riparian vegetation, which is mainly composed of chestnut trees. Stream 2 is less shaded than Stream 1 and the riparian vegetation is rnore diverse. The differences in riparian vegetation could be one factor explaining the differences in the taxonomic cornposition of the streams. In fact, Stream 1 has a higher input of particulate 
organic matter (personal observation) than Stream 2. However, shredders (the group potentially more affected by the differences in the supply of allochthonous organic matter) are more abundant in Stream 2, except in summer, when they are more abundant in Strcam 1. Stream 1 is extremely retentive and benthic particulate organic maltcr can be observed in the stream throughout the year (ABELHO \& GRACA, 1996). This pool of POM may be the reason for the greater abundance of shredders in Stream 1 during summer. On the other hand, JACOBSEN \& FRIBERG (1997) found that, for Danish streams, size is more important than the dcgrec of forcst cover in determining the species richness and community structure of the invertebrate fauna. Moreover, Psychodidae and Limoniidae were rnorc diverse in Stream I, which is in agreement with JACOBSEN \& FRIBEKC (1997) that found that these two families were more diverse in the small streams than in the larger ones.

The density of invertcbratcs collected during the study period $\left(1465-2365 \mathrm{~m}^{-2}\right)$ is within the ranges reported by other studies in Europe (JACOBSEN \& FRIBERG, 1997), South America (JACOBSEN et al., 1997), and New Zealand (FRIRERG et al., 1997), but arc much lower than the numbers reported by FRIBERG (1997) for Danish forest strcams.

The number of species obtained depends largely on the method and effort of sampling and identification. Considering that many groups (some usually considered very diverse in terms of spccies, such as chironomids and simulids), were incompletely identified, we can suppose that the taxonomic diversity of the streams is higher than showed here. Nevertheless, the number of taxa identificd from the study strcams (90 in Stream 1 and 83 in Stream 2) is high comparing to other stutlies. In a study where most insects were identified to specics, JACOBSEN \& FRIBERG (1997) reported a maximum of 77 taxa in small forest streams, and FRIBERG er al. (1997) reported a maximum of 40 taxa. Counting insect families and non-insect classes, JACOBSEN et al., (1997) rcportcd a maximum of 33 tax.a. Using the same criteria, at least 49 man were idcntificd in Stream 1 and 47 in Strcam 2.

From the functional point of view, Margaraqa Forest streams are similar to other forest streams (FRIBERG, 1997), bcinp dominated by collectors and shredders. The plecopteran Leuctra spp was the dominant detritivore, reaching $48 \%$ of the total invertebrate community in summer at Stream 1. According to FRIBERG (1997), the ratio between invertebrates with a life-cycle $\geq 2 \mathrm{yr}$ (such as the Leuctridae) and invertebrates with a life-cycle $\leq 1 \mathrm{yr}$ is determined by both the quantity and the quality of the detritus. Thus. the higher the ratio, the lower the quantity and/or quality of the detritus. If this is also true for South Europe, than the invertebrates of the streams in study were foodlimited, specially in summer at Stream 1.
The streams of Margaraça Forest have a high taxonomic richness. More important than divcrsity arc the taxonomic associations found in the streams of Margaraqa Forest (ABELHO \& GRACA, 1992; ABELHO, 1994; ABELHO \& GRACA, 1996). These suggest that the replacement of the original vegetation may cause irremediable loss of species.

Remnant patches of native forcst are important reserves for native insects (CRISP et al., 1998). Animal species with complex life-cycles contribute two doses of biological diversity to a community: as larvae in aquatic and as adults in terrestrial patches (HARPER \& HAWKSWORTH. 1995). The prescrvation of these patches should be a priority, specially in a country where afforestation with exotic species is taking place at a high rate.

In this paper we have shown that aquatic invertebrate diversity in an unperturbed area was high. However, bccausc only nearly one third of total taxa was fully identified, total diversity is surely much higher. It is therefore urgent to invest more in the formation of specialists in order to create conditions to evaluate local hiodiversity of arthropods and other important aquatic invertcbrates.

\section{ACKNOWLEDGMENTS}

This work was supported by Fundação para a Ciência e a Tecnologia (FCT), through a program grant (PEAM/C/CNT/ 31/91) and through a scholarship to M. Abelho (BM/2265/91. $\mathrm{RN})$.

\section{REFERENCES}

ABELHO, M. 1994. Reflorestação com Eucalipto: Efeitos nos Sistemas Ribeirinhos Baseados em Detritos. Master thesis. Department of Zoology, University of Coimbra.

ABELHO, M. \& GRACA, M.A.S. 1992. Comunidades aquáticas e cobertura vegctal: a reflorestação com cucaliptos. Actas do V Congresso Ibérico de Entomologia, 1: 395-404.

ABELHO, M. \& GRACA, M.A.S. 1996. Effects of eucalyptus afforestation on leaf litter dynamics and macroinvertebrate community structure of strcams in Central Portugal. Hydro. biologia, 324: 195-204

CRISP, P.N.; DICKINSON. K.J.M. \& GIBBS, G.W. 1998. Does native invertebrate diversity reflect native plant diversity? A case study from New Zealand and implications for conservation. Biological Conservation, 83: 209-220.

FRIBERG, N. 1997. Benthic invertebrate communities in six Danish forest streams: impact of forcst type on structure and function. Ecography, 20: 19-28. 
FRIRERG. N.: WINTERBOURN, M.J.; SHEARER, K.A. \& LARSEN, S.E. 1997. Henthic communities of forest streams in the South Island, New Zealand: effects of forest type and location. Archives fuir Hydrobiologie, 138: 289-306

HARPER \& HAWKSWORTH 1995. Preface: 5-12. In Biodiversity-measurement and estimation. (HAWKSWORTH, D.L. ed.). Chapman \& Hall. London SE1 8HN.

JACOBSEN, D. \& FRIBERG, N. 1997. Macroinvertebrate communities in Danish streams: the effect of riparian forest cover: 208-222. In Freshwater Biology-Priorities and development in Danish research (SAND-JENSEN, $K$. \& PEDERSEN. O. eds.). GEC Gad Publishers Ltd. DK-1161 Copenhagen.

JACOBSEN, D.; SCHULTZ, R. \& ENCALADA. A. 1997. Structure and diversity of stream invertebrate assemblages: the influence of temperature with altitude and latitude. Freshwater Biology, 37: 101-115.

MERRITT, R.W. \& CUMMINS, K.W. (eds.) 1996. An Introduction to the Aquatic Insects of North America. $3^{\text {rd }}$ ed. Kendall-Hunt Publishing Company, Dubuque. Iowa.

PAIVA. J.A.R. 1981. Mata da Margaraça c sua conversão ern rcserva. Anais da Sociedade Broteriana, 47: 49-66.

TACHET, H., BOURNAUD, M. \& RICHOUX, P. (1981). Introduction à l'Etude des Macroinvertebres des Eaux Douces. $3^{\text {rd }}$ ed. C.R.D.P. Lyon.

WARD, J.V. 1998. Riverinc landscapes: biodiversity patterns. disturbance regimes, and aquatic conservation. Biological Conservation, 83: 269-278.

ZAR, J.H. 1996. Biostatistical Analysis. $3^{\text {rd }}$ ed. Prenticc-Hall International.. Upper Saddle River. N.J. 07458. London. 


\section{APPENDIX}

List of the taxa collected in Stream 1 and Stream 2, in the 3 sampling seasons (ind $\mathrm{m}^{-2}$ ). Status: (A) abundant and regularly distributed taxa; (R) taxa occurring more or less regularly but not in great numbers; (O)taxa occurring occasionally; $\mathbf{1}$ in Stream I or $\mathbf{2}$ in Stream 2. A = Autumn. $\mathbf{W}=$ Winter, $\mathrm{S}=$ Summer.

\begin{tabular}{|c|c|c|c|c|c|c|c|}
\hline \multirow[b]{2}{*}{ Taxa } & \multirow[b]{2}{*}{ Status } & \multicolumn{3}{|c|}{ Stream 1} & \multicolumn{3}{|c|}{ Stream 2} \\
\hline & & $\mathrm{A}$ & $\mathrm{W}$ & $\mathrm{S}$ & $\mathrm{A}$ & $\mathrm{W}$ & $\mathrm{S}$ \\
\hline Polycelis nigra/temuis & $(\mathbf{R})^{-}$ & 5 & 11 & 63 & 1 & 13 & 0 \\
\hline Tricladida unidentified 1 & (O) & 0 & 0 & 4 & 0 & 4 & 0 \\
\hline Nematoda & $\left(R_{1}\right)$ & 0 & 2 & 4 & 0 & 0 & 0 \\
\hline Valvata cf piscinalis & (O) & 1 & 0 & 0 & 2 & 0 & 0 \\
\hline Ancylus fluviatilis & (R) & 8 & 1 & 0 & 6 & 5 & 10 \\
\hline Gastropoda unidentified $l$ & $\left(\mathbf{R}_{1}\right)$ & 0 & 1 & 2 & 0 & 0 & 0 \\
\hline Sphaerium corneum & (R) & 61 & 3 & 35 & 10 & 2 & 3 \\
\hline Lumbriculus varzegatus & (A) & 244 & 39 & 81 & 200 & 165 & 166 \\
\hline Tubificidae & $\left(\mathbf{R}_{1} \mathbf{O}_{2}\right)$ & 0 & 37 & 6 & 0 & 3 & 0 \\
\hline Naididae & (A) & 0 & 131 & 8 & 24 & 24 & 119 \\
\hline Eiseniella tetraedra & $\left(\mathbf{R}_{1} \mathbf{O}_{2}\right)$ & 3 & 0 & 5 & 0 & 1 & 0 \\
\hline Glossiphonia complanata & $\left(\mathrm{O}_{1}\right)$ & 0 & 1 & 0 & 0 & 0 & 0 \\
\hline Glossiphonza heteroclita & $\left(\mathbf{O}_{2}\right)$ & 0 & 0 & 0 & 0 & 1 & 0 \\
\hline Erpobdella monostriata & (O) & 0 & 0 & 15 & 0 & 3 & 0 \\
\hline Erpobdella testacea & (O) & 2 & 0 & 0 & 1 & 0 & 0 \\
\hline Hydracarina & $\left(\mathrm{R}_{1} \mathrm{O}_{2}\right)$ & 1 & 2 & 1 & 0 & 4 & 0 \\
\hline Isopoda unidentified 1 & (O) & 1 & 0 & 0 & 1 & 0 & 0 \\
\hline Isopoda unidentified 2 & $\left(\mathrm{O}_{1}\right)$ & 2 & 0 & 0 & 0 & 0 & 0 \\
\hline Isopoda unidentified 3 & $\left(\mathrm{O}_{1}\right)$ & 2 & 0 & 0 & 0 & 0 & 0 \\
\hline Collembola & $\left(\mathbf{O}_{1} \mathbf{R}_{2}\right)$ & 0 & 3 & 0 & 3 & 2 & 0 \\
\hline Baetis sp & $\left(\mathbf{R}_{1} A_{2}\right)$ & 15 & 67 & 4 & 12 & 213 & 4 \\
\hline Epeorus torrentium/sylvicola & (R) & 46 & 1 & 0 & 5 & 4 & 0 \\
\hline Ecdyonurus aurantiacus & (R) & 5 & 1 & 1 & 5 & 31 & 14 \\
\hline Ephemerellaignita/mesoleuca & $\left(\mathrm{O}_{2}\right)$ & 0 & 0 & 0 & 0 & 287 & 0 \\
\hline Paraleptophlebia submarginata & (R) & 23 & 80 & 0 & 1 & 3 & 0 \\
\hline Ephemera glaucops & $\left(\mathbf{R}_{2}\right)$ & 0 & 0 & 0 & 33 & 13 & 0 \\
\hline Ephemera lineata & $\left(\mathbf{A}_{2}\right)$ & 0 & 0 & 0 & 7 & 1 & 88 \\
\hline Nemoura cinerea & (O) & 0 & 1 & 0 & 1 & 0 & 0 \\
\hline Nemaura linguata & $\left(\mathrm{O}_{1}\right)$ & 1 & 0 & 0 & 0 & 0 & 0 \\
\hline Nemoura uncinata & (R) & 8 & 10 & 9 & 1 & 1 & 0 \\
\hline Protonemura sp & (A) & 34 & 36 & 82 & 11 & 128 & 0 \\
\hline Leuctra gr. aurita & $\left(\mathbf{R}_{1} \mathbf{A}_{2}\right)$ & 20 & 3 & 28 & 20 & 0 & 117 \\
\hline Leuctra despaxi & (R) & 33 & 0 & 7 & 32 & 0 & 32 \\
\hline Leuctra gr. fusca & $\left(\mathbf{R}_{\mathbf{1}} \mathbf{A}_{2}\right)$ & 6 & 24 & 55 & 28 & 117 & 36 \\
\hline Leuctra sp5 & (A) & 301 & 97 & 607 & 402 & 119 & 267 \\
\hline Perla burmeisteriana & $\left(\mathrm{O}_{1}\right)$ & 0 & 1 & 0 & 0 & 0 & 0 \\
\hline Perla marginata & $\left(\mathrm{O}_{1}\right)$ & 0 & 4 & 0 & 0 & 0 & 0 \\
\hline Siphonoperla torrentium/baetica & $\left(O_{1}\right)$ & 0 & 11 & 0 & 0 & 0 & 0 \\
\hline
\end{tabular}




\begin{tabular}{|c|c|c|c|c|c|c|}
\hline Calopteryx splendens & $\left(\mathrm{O}_{2}\right)$ & 0 & 0 & 0 & 1 & 0 \\
\hline Calopteryx virgo & $\left(\mathbf{R}_{2}\right)$ & 0 & 0 & 0 & 2 & 1 \\
\hline Cordulegasterboltonii & (R) & 1 & 1 & 1 & 1 & 1 \\
\hline cf. Hydroporus sp (adults) & $\left(\mathrm{O}_{2}\right)$ & 0 & 0 & 0 & 1 & 0 \\
\hline Deronectes sp (adults) & $\left(\mathrm{O}_{1}\right)$ & 0 & 1 & 0 & 0 & 0 \\
\hline Copelatus sp (larvae) & $\left(O_{1}\right)$ & 0 & 2 & 0 & 0 & 0 \\
\hline Agabus sp (larvae) & $\left(\mathbf{O}_{1}\right)$ & 0 & 2 & 0 & 0 & 0 \\
\hline Agabus sp (adults) & $\left(\mathrm{O}_{1}\right)$ & 0 & 1 & 0 & 0 & 0 \\
\hline Hydraena sp (adults) & $\left(\mathrm{O}_{2}\right)$ & 0 & 0 & 0 & 0 & 6 \\
\hline Anacaena sp (adults) & $\left(\mathrm{O}_{1}\right)$ & 0 & 1 & 0 & 0 & 0 \\
\hline Enochrus sp (adults) & $\left(\mathrm{O}_{1}\right)$ & 0 & 0 & 1 & 0 & 0 \\
\hline Limnichus pygmaeus (adults) & $\left(\mathbf{O}_{1}\right)$ & 0 & 1 & 0 & 0 & 0 \\
\hline Eubria sp (larvae) & $\left(\mathrm{O}_{2}\right)$ & 0 & 0 & 0 & 3 & 0 \\
\hline Dryops sp (larvae) & $\left(\mathrm{O}_{2}\right)$ & 0 & 0 & 0 & 5 & 0 \\
\hline Dryops sp (adults) & $\left(\mathrm{O}_{1}\right)$ & 0 & 1 & 0 & 0 & 0 \\
\hline Elmis sp (larvae) & $\left(\mathbf{R}_{2}\right)$ & 0 & 0 & 0 & 1 & 9 \\
\hline Elmis sp (adults) & $\left(\mathbf{O}_{2}\right)$ & 0 & 0 & 0 & 0 & 4 \\
\hline Esolus sp (larvae) & $\left(\mathrm{O}_{2}\right)$ & 0 & 0 & 0 & 0 & 4 \\
\hline Esolus sp (adults) & (O) & 0 & 0 & 1 & 2 & 0 \\
\hline Coleoptera unidentified 1 (adults) & $\left(\mathrm{O}_{2}\right)$ & 0 & 0 & 0 & 0 & 1 \\
\hline Coleoptera unidentified 3 (larvae) & $\left(\mathrm{O}_{2}\right)$ & 0 & 0 & 0 & 0 & 1 \\
\hline Rhyacophila adjuncta/denticulata & $\left(\mathbf{R}_{\mathbf{l}}\right)$ & 1 & 0 & 1 & 0 & 0 \\
\hline Rhyacophila eatoni/tristis & $\left(\mathbf{R}_{1} \mathbf{O}_{2}\right)$ & 24 & 5 & 8 & 0 & 2 \\
\hline Rhyacophilapulchra & $\left(\mathbf{R}_{1} \mathbf{O}_{2}\right)$ & 4 & 0 & 1 & 0 & 2 \\
\hline Agapefussp & (R) & 10 & 4 & 1 & 4 & 23 \\
\hline Hydroptila $\mathrm{sp}$ & $\left(\mathrm{O}_{2}\right)$ & 0 & 0 & 0 & 0 & 0 \\
\hline Philopotamus montamus & $\left(\mathbf{R}_{1} \mathbf{O}_{2}\right)$ & 7 & 0 & 5 & 0 & 0 \\
\hline Diplectronafelix/moralesi & (R) & 59 & 8 & 23 & 22 & 73 \\
\hline Hydropsyche bulbifera & $\left(\mathbf{R}_{2}\right)$ & 0 & 0 & 0 & 4 & 10 \\
\hline Hydropsyche instabilis & $\left(\mathrm{O}_{2}\right)$ & 0 & 0 & 0 & 0 & 1 \\
\hline Hydropsyche siltalai & $\left(\mathbf{O}_{1} \mathbf{R}_{2}\right)$ & 0 & 0 & 3 & 4 & 7 \\
\hline Hydropsyche tibialis & (R) & 2 & 0 & 6 & 1 & 1 \\
\hline Plectrocnemia geniculafa & $\left(\mathbf{R}_{1}\right)$ & 0 & 3 & 6 & 0 & 0 \\
\hline Polycentropus flowomaculatus & $\left(\mathrm{O}_{2}\right)$ & 0 & 0 & 0 & 0 & 0 \\
\hline Lype phaесора & $\left(\mathrm{O}_{1}\right)$ & 0 & 0 & 2 & 0 & 0 \\
\hline Lype reducta & $\left(\mathbf{O}_{2}\right)$ & 0 & 0 & 0 & 0 & 0 \\
\hline Metalype fragilis & $\left(\mathrm{O}_{1}\right)$ & 2 & 0 & 0 & 0 & 0 \\
\hline Ecnomus sp & $\left(\mathrm{O}_{2}\right)$ & 0 & 0 & 0 & 0 & 0 \\
\hline Limnephilus sp & $\left(\mathbf{O}_{2}\right)$ & 0 & 0 & 0 & 7 & 0 \\
\hline cf. Micropterna sp & $\left(\mathbf{R}_{1}\right)$ & 8 & 1 & 0 & 0 & 0 \\
\hline Allogamus sp & (R) & 0 & 10 & 2 & 0 & 2 \\
\hline cf. Lithax niger & $\left(\mathbf{R}_{2}\right)$ & 0 & 0 & 0 & 1 & 1 \\
\hline Thremma gallicum & $\left(\mathbf{O}_{1} \mathbf{R}_{2}\right)$ & 0 & 0 & 2 & 1 & 4 \\
\hline Lepidostoma hirtum & $\left(\mathbf{R}_{2}\right)$ & 0 & 0 & 0 & 6 & 0 \\
\hline Crunoecia irrorata & $\left(\mathbf{R}_{1}\right)$ & 9 & 16 & 0 & 0 & 0 \\
\hline Adicella filicornis & $\left(\mathbf{O}_{1}\right)$ & 0 & 3 & 0 & 0 & 0 \\
\hline Adicella meridionalis/reducta & $\left(\mathbf{O}_{1} \mathbf{R}_{2}\right)$ & 3 & 0 & 0 & 0 & 5 \\
\hline$c f$. Sericostoma sp & (R) & 21 & 0 & 10 & 52 & 10 \\
\hline Beraea pullata & (R) & 7 & 8 & 14 & 1 & 2 \\
\hline Calamoceras marsupus & $\left(\mathbf{O}_{1}\right)$ & 0 & 1 & 0 & 0 & 0 \\
\hline
\end{tabular}




\begin{tabular}{|c|c|c|c|c|c|c|c|}
\hline Apistomyia sp & $\left(\mathrm{O}_{2}\right)$ & 0 & 0 & 0 & 0 & 2 & 0 \\
\hline Liponeura sp & $\left(\mathrm{O}_{2}\right)$ & 0 & 0 & 0 & 4 & 0 & 0 \\
\hline Tipula sp & (R) & 2 & 1 & 3 & 6 & 1 & 1 \\
\hline Helius sp & $\left(\mathbf{R}_{1}\right)$ & 4 & 1 & 0 & 0 & 0 & 0 \\
\hline Pedicia sp & $\left(O_{1}\right)$ & 0 & 2 & 0 & 0 & 0 & 0 \\
\hline Dicranota sp & $\left(\mathbf{R}_{1}\right)$ & 4 & 1 & 1 & 0 & 0 & 0 \\
\hline Hexatoma sp & (R) & 1 & 9 & 1 & 3 & 0 & 1 \\
\hline Erioptera sp & $\left(\mathrm{O}_{2}\right)$ & 0 & 0 & 0 & 0 & 2 & 0 \\
\hline Molophilus sp & $\left(\mathrm{O}_{2}\right)$ & 0 & 0 & 0 & 1 & 0 & 0 \\
\hline Gonomyia sp & $\left(\mathrm{O}_{1}\right)$ & 2 & 0 & 0 & 0 & 0 & 0 \\
\hline Limoniidae unidentified 4 & $\left(\mathrm{O}_{2}\right)$ & 0 & 0 & 0 & 1 & 0 & 0 \\
\hline Psychodidae unidentified 1 & $\left(\mathrm{O}_{1}\right)$ & 1 & 0 & 0 & 0 & 0 & 0 \\
\hline Psychodidae unidentified 2 & $\left(\mathbf{R}_{\mathbf{1}}\right)$ & 2 & 0 & 1 & 0 & 0 & 0 \\
\hline Psychodidae unidentified 3 & $\left(\mathrm{O}_{1}\right)$ & 2 & 0 & 0 & 0 & 0 & 0 \\
\hline Psychodidae unidentified 7 & $\left(\mathrm{O}_{1}\right)$ & 0 & 0 & 3 & 0 & 0 & 0 \\
\hline Dixa maculata & $\left(\mathbf{R}_{2}\right)$ & 0 & 0 & 0 & 3 & 0 & 1 \\
\hline Dixa puberula & (R) & 1 & 5 & 1 & 1 & 1 & 0 \\
\hline Simuliidae & (A) & 294 & 28 & 119 & 239 & 126 & 27 \\
\hline Tanypodinae & $\left(\mathbf{A}_{1} \mathbf{R}_{2}\right)$ & 4 & 251 & 2 & 15 & 56 & 28 \\
\hline Corynoneura $\mathrm{sp}$ & (R) & 17 & 17 & 0 & 2 & 2 & 0 \\
\hline Orthocladiinae & (A) & 687 & 883 & 162 & 267 & 154 & 350 \\
\hline Chironomini & $\left(\mathbf{A}_{1} \mathbf{R}_{2}\right)$ & 39 & 122 & 12 & 35 & 82 & 41 \\
\hline Tanytarsini & $\left(A_{1} R_{2}\right)$ & 204 & 397 & 42 & 21 & 117 & 21 \\
\hline Bezzia sp & $(\mathbf{R})$ & 5 & 2 & 3 & 3 & 9 & 7 \\
\hline Thaumaleidae & $\left(\mathbf{O}_{1}\right)$ & 0 & 1 & 0 & 0 & 0 & 0 \\
\hline Stratiomysa sp & $\left(\mathbf{O}_{1}\right)$ & 0 & 2 & 0 & 0 & 0 & 0 \\
\hline Hemerodromiinae & (R) & 0 & 2 & 2 & 0 & 8 & 6 \\
\hline Atalantinae & (R) & 2 & 4 & 4 & 1 & 2 & 2 \\
\hline Dolichopodidae & (R) & 25 & 1 & 2 & 7 & 11 & 10 \\
\hline Atherix sp & (R) & 1 & 0 & 1 & 48 & 71 & 66 \\
\hline Anthomyidae & $\left(\mathrm{O}_{1}\right)$ & 1 & 0 & 0 & 0 & 0 & 0 \\
\hline Diptera unidentified & $\left(O_{1}\right)$ & 0 & 0 & 2 & 0 & 0 & 0 \\
\hline Total ind $\mathrm{m}^{-2}$ & & 2278 & 2365 & 1465 & 1582 & 1958 & 1477 \\
\hline Number of taxa & & 56 & 60 & 53 & 90 & 58 & 60 \\
\hline
\end{tabular}

